\title{
TERRITORIAL-TECHNICAL AND SOCIO-ECONOMIC ASPECTS OF SUCCESSFUL BROWNFIELD REGENERATION: A CASE STUDY OF THE LIBEREC REGION (CZECH REPUBLIC)
}

\author{
Jakub ČERNÍK ${ }^{1}$, Josef KUNC ${ }^{1}$, Stanislav MARTINÁT ${ }^{2}$
}

DOI: 10.21163/GT_2016.112.03

\begin{abstract}
:
When looking for new uses for unused areas and buildings, it is essential to consider the context of the area, especially from the territorial-technical, spatial, socio-demographic, economic and urbanistic points of view. In order to find new uses for brownfields which will be sustainable in the long term, it is necessary to employ tools that enable holistic evaluation of the mutual relationship between brownfields and their surroundings so that the most suitable future use can be identified. In the present contribution the brownfields in the Liberec Region (Czech Republic), which is known for its ragged terrain and distinct industrial past, were subjected to this evaluation. Methodically, the contribution is based on principal component analysis and variance analysis (20 composed factors). The results indicate that in several cases apparent differences in the environment of neglected areas can be observed, whether based on previous use or between regenerated sites and sites falling into disrepair. The results of the performed tests show that the environment where brownfields occur differs in some cases, especially when comparing the past and present uses and the current state of their regeneration.
\end{abstract}

Key-words: Brownfields, Aspects of Successful Regeneration, Spatial Planning, Principal Component Analysis, Liberec Region (Czech Republic)

\section{INTRODUCTION}

When discussing brownfields, it is necessary to consider the complexity of the issue, which stems not only from the high concentration and variability of the obstacles occurring in the territory, but also from the needs that the stakeholders expect the devastated areas to fulfil. A clear vision regarding the new uses and functions of the regenerated area shared amongst the main participants is generally considered a key starting factor, which is a necessary precondition for a successful revitalization of the area (Adair et al, 2000; Prato, 2007). Mutual communication and a shared idea of the methods of work and the future uses constitutes a solid foundation for overcoming problems, which may arise during the realization of the work, as well as during negotiations of compromises about the partial interests of the individual stakeholders (Duinker \& Greig, 2007).

The pressure to use the already developed areas heavily is all the more important, considering that is it fully contained within the intentions of sustainable regional development, specifically circular land management (Ferber, Jackson \& StarzewskiSikorska, 2011) by means of protecting undeveloped land (Bardos, Nathanail \& Weenk, 2000). In order for stakeholders to achieve the best results in the effective utilization of

\footnotetext{
${ }^{1}$ Masaryk Universit, Faculty of Economics and Administration, 61300 Brno, Czech Republic, cernik@mail.muni.cz,kunc@econ.muni.cz;

${ }^{2}$ Silesian University in Opava, School of Business Administration in Karviná,, 73340 Karviná, Czech Republic,martinat@opf.slu.cz.
} 
brownfields, it is essential to use sophisticated tools which create support during decisionmaking processes.

For quite some time, environmental and spatial decision support systems have been one of the ways to support analysis and the decision-making process in the management of brownfield regeneration (Ascough et al, 2008; Malczewski, 2006). However, recent studies have identified a lack of similar support tools which are complex enough to evaluate various different regeneration scenarios from the socio-economic point of view while respecting the environmental and territorial characteristics of the area (Agostini \& Vega, 2007; Filip \& Cocean, 2012; Gregory \& Slovic, 1997; Jakeman et al, 2008; Popescu \& Pătrăşcoiu, 2012; Tam \& Byer, 2002). The existing utilized tools usually assess already existing and formulated regeneration scenarios (i.e. the future uses of brownfields), implying that these tools will only be utilized once the most significant decisions, that is, the future functions of the areas, have been made. Currently, this condition must already be fulfilled when using holistic assessment methods (Carlon et al, 2007; Schädler et al, 2011; Wedding \& Crawford-Brown, 2007), but also methods that only assess one particular aspect of the regeneration - for example the effect on population health (McKnight et al, 2010), or regeneration costs (Bayer, Finkel \& Teutsch, 2005).

Investments in brownfield regeneration always pose an increased risk compared to construction in greenfields (Adair et al, 2002). Compared to undeveloped areas, the resurrection of brownfields brings the risk of familiar (structure of property rights, buildings in desolate condition) and also unpredictable obstacles (lack of information on ecologic contamination, non-existent blueprints), which disqualify the areas on the real estate market (where they create competition for developments in greenfields).

In spite of this, there has been an apparent emphasis on sustainable land use in recent years, which has brought the attention on local authority representatives and investors to devastated areas (e.g. Nijkamp, Rodenburg \& Wagtendonk, 2002). It is therefore necessary to develop tools which can assess the benefits and the costs following regeneration of devastated areas in order to make decisions about the direction and manner of settlement development. One of the Decision Support Systems (DSS), which can be used to obtain data for deciding about possible scenarios for future development of devastated areas is spatial analysis (Agostini \& Vega, 2007; and others). There are a number of tools that allow the assessment of brownfields, usually with respect to environmental risks associated with contaminated sites. Stezar et al (2013) react to the needs arising from the major European projects TIMBRE and HOMBRE in their overview (www.timbre-project.eu; www.zerobrownfields.eu).

Spatial analysis is used especially in assessment of brownfield attractiveness in a larger context of the area. Oliver et al (2005) focused on researching the regional differences in the number of devastated sites and regenerated brownfields relating to economic and demographic indicators on a national level. They completely downplayed the potential presence of contaminated soil and emphasized the development potential of the area. This approach is based on the assumption that a successful brownfield regeneration must be perceived in the context of the whole region and its economic, social and environmental characteristics (Hayek et al, 2010). The next starting point leading to the choice of this approach is the fact that, even though brownfields are also being regenerated in the Central European region in recent years, it is often due to the influence of foreign funds. Foreign companies invest these in projects, the profit rates of which are determined on the basis of the economic environment of the region (Viturka et al, 2010; Frantál et al, 2013). 
Spatial dimension is conceived in terms of brownfield position in the morphogenetic zone of the city or the urbanized area (e.g. Kunc et al, 2014), or conversely, as part of peripheral and rural regions (Klusáček et al, 2011) in many works. These works are generally concerned with analysis of brownfields by means of numerous attributes, tracing their common characteristics and the subsequent design of brownfield classification. In contrast, some authors attempt to identify the development potential of brownfields. Doetsch and Rüpke (1998), and also Rydvalová (2006) in a slightly modified version, propose to follow previously defined economically underdeveloped regions when prioritizing brownfields. Despite its logical basis, it is not possible to fully agree with this approach, since there is no apparent link between the occurrence of brownfields and the defined economically weak regions.

\section{METHODOLOGY}

The area of the Liberec Region was chosen as a model region. With its rugged terrain and its previously sectoral composition of industry, which draws on a long tradition of textile and glass production in the region, a fairly specific research area is created. These facts must be taken into account during the potential generalization of results for the whole territory of the Czech Republic. The Liberec Region, located in the northern part of Bohemia, is the second smallest region of the Czech Republic, in terms of both area $(3,163$ $\mathrm{km} 2$ ) and population (439,000 inhabitants). A part of the outline of the region forms a border with Poland and to a lesser extent with Germany. There are 216 municipalities in the region, while in more than half of them (114) brownfields are recorded.

Data from publicly accessible databases managed by public authorities have been used as the source data. The agency CzechInvest (The CzechInvest Agency, 2008) has mapped the brownfields in the Czech Republic within the creation of the National brownfield regeneration strategy (2008), during which 2,355 brownfields were localized, 275 of which are located in the territory of the Liberec Region. The Database of areas of the brownfield type, managed by the Regional Development Agency of the Liberec Region since 2007 with its 346 records was another key source. A total of 378 unique records were used for the analysis. Information from the databases has been updated at the end of 2013 (see Fig.1). Thanks to the update, it was possible to identify the brownfields, which were revitalized or found new use in the monitored period of 2007-2013. This way a control file comprising the sites was acquired, and the created model which indicated the regeneration potential of brownfields was compared to it during the next phase of testing.

The aim of this research is to identify the existence of a relationship between the devastated sites and the environment where they occur. The starting point of the research is the presumption that the use of the site is determined by the surrounding environment, be it from the geomorphological, demographic, social, or an entrepreneurial point of view. In order to capture these characteristics 20 composed factors were chosen, which were used to describe the environment where the brownfields occurred, as well as territorial relationships with the area.

A total of 20 indicators that primarily describe the economic, demographic and spatialtechnical characteristics of the environments where brownfields occur have been selected for an analysis of the factors influencing successful brownfield regeneration. The first group of analyzed variables takes into account the area of the brownfields (for example the area of the brownfields compared with the total area of the municipality) or describes the space in terms of land utilization (for example the ratio of forested areas within the total 
area of the municipality). A relatively significant number of these factors could be explained by the initial presumption that economic activities, which have a major impact on brownfield regeneration, are reflected in territorial relationships.

\section{TYPOLOGY OF BROWNFIELDS FORMER FUNCTION IN LIBEREC REGION}

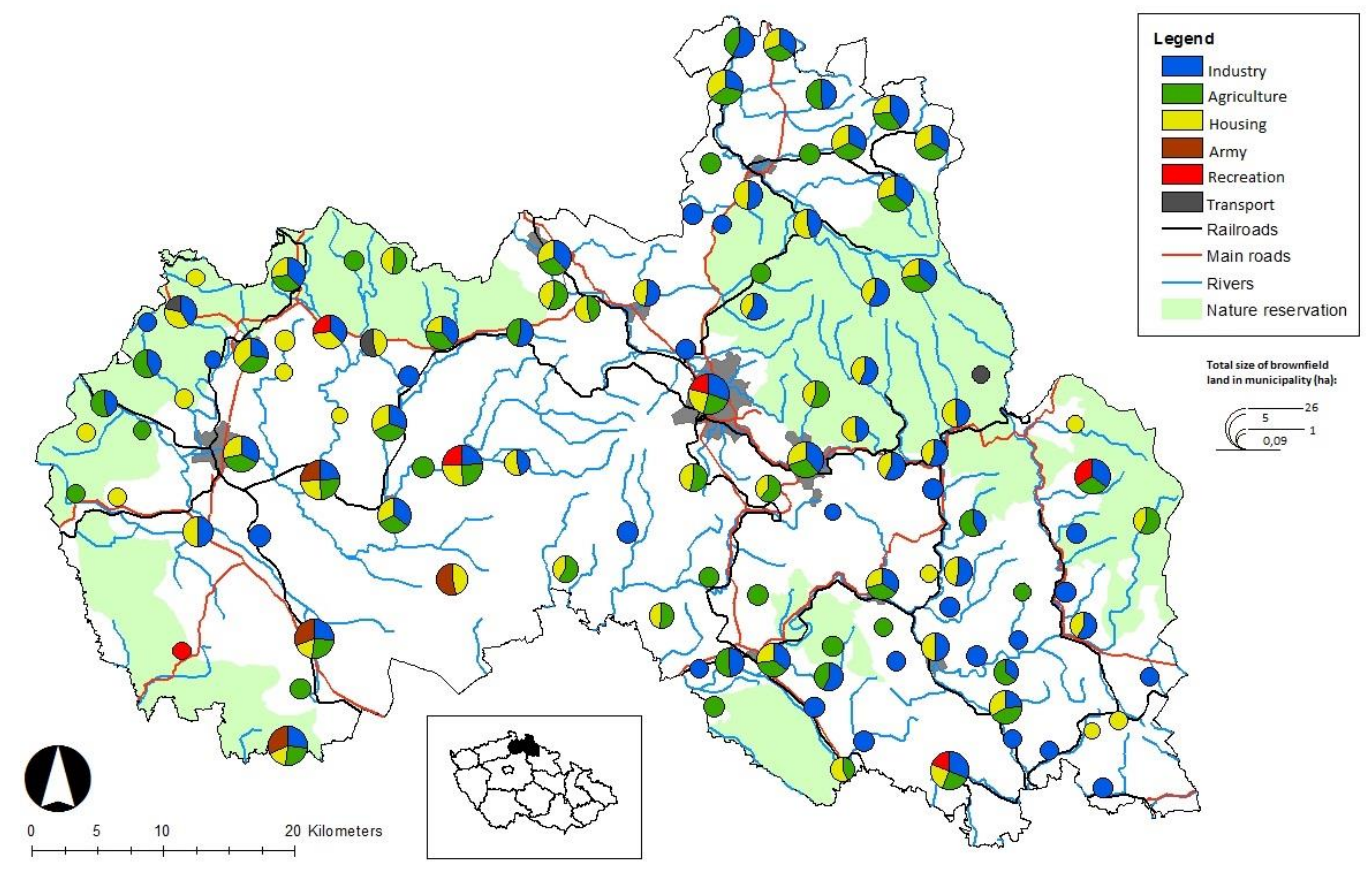

Fig. 1 Typology of Brownfields by Former Function in Liberec Region

(Source: CzechInvest, Liberec Region, own research (The CzechInvest Agency, 2008)).

Other indicators describe the demographic (the proportion of economically active population) and economic activity in a municipality with extended competence (e.g. number of tradesmen among 1000 inhabitants). Finally, the last group of analyzed factors captures spatial-geographic aspects of individual brownfields, for example peripheral nature of the municipality measured by distances of the areas from transport infrastructure. The composition of the factors was inspired by previous research, which applied elements of factor analysis to the issue of brownfields (Chrysochoou et al, 2012; Frantál et al, 2013, and others). In order to respect time consecution, the date 31. 12. 2013 was used when composing the individual descriptive factors. Only in the case of factors that were constructed using demographic and socio-economic data (Namely the factors Population density, Number of inhabitants, Entrepreneurial activity, Unemployment and ratio of free workplaces compared to economically active population.) the average data from the ends of the years 2007-2013 was used. 


\section{RESULTS}

\subsection{Dimension formulation}

Before starting the analysis, the values of tracked variables, captured in different units, were transformed into new variables, whose indexation (values of the new variables ranged from 0 to 1) enabled a factor analysis. In this phase, two formulas were applied. The application of these allows efficient standardization of data in the required range of 0-1 and depends on the direction in which the quality of the observed phenomenon grows. For factors, whose quality increases with increasing value, the following formula was used (This is the formula that served for calculating the human development index (HDI) in the years 1990-2010 (Anand \& Amatya, 1994):

$$
I_{x i}=\frac{x_{i}-x_{\min }}{x_{\max }-x_{\min }}
$$

And for factors, whose quality increases with decreasing value, the following formula was used:

$$
I_{x i}=\frac{x_{\max }-x_{i}}{x_{\max }-x_{\min }}
$$

Due to the relatively large file of analyzed variables, which can be expected to correlate, their number was reduced in order to increase clarity using principal component analysis with an Oblimin rotation (Bernard, 2011, Frantál et al, 2013). The rotation solution was chosen because of the possible existence of mutual correlation of some of the factors analyzed. This can be assumed based on the structure of factors describing the territorial relationships of devastated territory to outside environment. In such cases, oblique axis rotation enables a more definite saturation of dimensions by the individual indicators. In the first stage of analysis, a Monte Carlo simulation has been carried out, thanks to which it was possible to determine five independent dimensions using their own values. The dimensions can be extracted from the data file while maintaining the data structure (Kreinin et al, 1998) (see Table 1).

The adequacy of the selected dimensions can be verified using the Kaiser-Meyer-Olkin measure of selection adequacy (KMO), which tested the correlation coefficients and the size of the coefficients of partial correlation. In our case, the $\mathrm{KMO}=0.666$, which indicates a satisfactory degree of correlation (The data file is suitable for factor analysis if the KMO ranges from $0.5-1$, while established practice considers data which show KMO $>0.8$ to be very reliable. (Tabachnik \& Fidell, 2001) between the pair variables for the interpretation through other variables. Therefore the factor analysis can be correctly applied to the data file. This conclusion is also confirmed by the results of the Barlett sphericity test, as it has rejected the hypothesis about a unit correlation matrix. The construction of five composed dimensions explains $59 \%$ of the original data file, which can be considered satisfactory. 
Table 1. Factor analysis of the main components of the factors affecting the successful regeneration of brownfields - factor dimension filling.

\begin{tabular}{|c|c|c|c|c|c|}
\hline & $\begin{array}{c}\text { Socio- } \\
\text { economic } \\
\text { structure } \\
\end{array}$ & $\begin{array}{c}\text { Peripheral } \\
\text { nature of } \\
\text { area } \\
\end{array}$ & $\begin{array}{l}\text { Economic } \\
\text { profile }\end{array}$ & $\begin{array}{l}\text { Significance } \\
\text { of area }\end{array}$ & $\begin{array}{l}\text { Regional } \\
\text { devastation }\end{array}$ \\
\hline $\begin{array}{r}\text { Population density } \\
\text { (people/km2) }\end{array}$ & .990 & .004 & .018 & -.006 & -.029 \\
\hline $\begin{array}{r}\text { Proportion of } \\
\text { regional devastation } \\
\text { (BF in } \\
\text { municipality/BF in } \\
\text { municipality with } \\
\text { extended } \\
\text { competence) }\end{array}$ & .990 & .005 & .019 & -.006 & -.028 \\
\hline $\begin{array}{l}\text { Number of } \\
\text { inhabitants }\end{array}$ & .988 & .014 & .013 & -.009 & -.031 \\
\hline $\begin{array}{r}\text { Entrepreneurial } \\
\text { activity }\end{array}$ & .982 & .026 & .033 & -.011 & -.034 \\
\hline area (ha) & .968 & .032 & .013 & -.012 & -.036 \\
\hline Unemployment & .878 & -.046 & .016 & .003 & .010 \\
\hline $\begin{array}{r}\text { Proportion of } \\
\text { devastation (set } \\
\text { BF/BF in } \\
\text { municipality) }\end{array}$ & .319 & -.004 & -.068 & .012 & .265 \\
\hline $\begin{array}{r}\text { Rate of devastation } \\
\text { (BF/developed) }\end{array}$ & .050 & .876 & .005 & -.166 & -.195 \\
\hline $\begin{array}{r}\text { Rate of overall } \\
\text { devastation (BF/total) }\end{array}$ & .059 & .822 & -.057 & -.391 & -.145 \\
\hline $\begin{array}{r}\text { proximity to regional } \\
\text { center ORP }(\mathrm{m})\end{array}$ & .034 & .648 & -.077 & .089 & -.025 \\
\hline $\begin{array}{r}\text { Distance to } \\
\text { expressway/highway }\end{array}$ & -.058 & .301 & -.010 & .059 & .096 \\
\hline $\begin{array}{r}\text { Rate of agriculture } \\
\text { (arable/total) }\end{array}$ & .065 & .008 & .984 & .075 & .060 \\
\hline $\begin{array}{r}\text { Rate of afforestation } \\
\text { (forested/total) }\end{array}$ & .065 & .008 & .984 & .075 & .060 \\
\hline $\begin{array}{r}\text { Free work } \\
\text { positions/EAP }\end{array}$ & -.054 & -.103 & .417 & -.121 & -.100 \\
\hline $\begin{array}{r}\text { Proportion of BF on } \\
\text { municipality area (set } \\
\text { BF/total area) }\end{array}$ & .015 & .094 & -.026 & -.987 & .088 \\
\hline $\begin{array}{r}\text { Proportion of BF on } \\
\text { devastation in } \\
\text { municipality (set } \\
\text { BF/developed areas) }\end{array}$ & .012 & .032 & .017 & -.985 & .102 \\
\hline $\begin{array}{r}\text { Proportion of } \\
\text { regional devastation } \\
\text { (set BF/BF in } \\
\text { municipality with } \\
\text { extended } \\
\text { competence) }\end{array}$ & -.191 & .131 & .056 & -.007 & -.722 \\
\hline
\end{tabular}




\begin{tabular}{|r|r|r|r|r|r|}
\hline $\begin{array}{r}\text { Urbanization } \\
\text { (developed/total) }\end{array}$ & -.128 & -.155 & -.062 & -.144 & .629 \\
\hline $\begin{array}{r}\text { Distance to railway } \\
\text { station (m) }\end{array}$ & -.067 & .287 & .184 & .018 & .469 \\
\hline $\begin{array}{r}\text { distance to 1st grade } \\
\text { road (m) }\end{array}$ & .015 & -.138 & .021 & -.078 & -.162 \\
\hline
\end{tabular}

Note: Principal component analysis, rotation solution by means of the method Oblimin. Indicated values are the highest absolute correlation of items; values exceeding \pm 0.3 are highlighted, indicators satiating individual dimensions are color coded.

Source: The Czech Statistical Office, CzechInvest, own calculations (The CzechInvest Agency, 2008).

The analyzed indicators can be organically broken down into several groups according to the described phenomena. The dimension of factors describing mainly the particular socio-demographic characteristics of the areas in which the devastated sites are located, is constructed in the most robust way. In the construction of most of the factors, the number of inhabitants of the area was taken into account when saturating the first dimension, which causes very similar amounts of dimension saturation by these factors. On the basis of the results obtained, factors which consider particular brownfields in the context of all devastated area in the municipality, or the devastated area in a certain municipality compared to the devastated area in the administrative region, were included in the first dimension. However, the last indicator does not greatly influence the values obtained at each site in the first dimension.

The design of the second dimension explains the peripheral nature of the site, because the ratio of total devastated land in the developed area to the total area of the municipality saturates it most significantly. Furthermore, it is significantly saturated by the distance of brownfields from the highway and from the regional administrative center. Factors of regional significance to the devastated sites may therefore indicate a greater potential for long-term deterioration of brownfields, which is also confirmed by the results of the subsequent analyses.

The third dimension describes the rural economic nature of the environment in which brownfields occur, as it is significantly saturated by the proportion of forested area in the municipality, and to a lesser extent by the proportion of area of arable land in the municipality. This may indicate a certain remoteness and low population density of the territory due to the generally barren submontane terrain of the region. A low number of inhabitants may indicate a third factor incorporated into the third dimension, and that is the number of available work positions relating to the economically active population, where higher values indicate a lack of manpower in the municipality.

The fourth dimension describes the territorial significance of the specific brownfields, as it relates its area to the developed area and total area of the municipality. These two factors show the same trends in saturation of individual dimensions, since their construction indicates a high likelihood of mutual correlation, which was confirmed by carrying out a correlation analysis.

The last dimension covers the overall territorial negligence of the administrative region where a specific site is located. It is possible to assume, based on the saturation of the dimension by individual factors, that the lower the proportion of a particular brownfield in the total neglected area in the administrative region, the more likely it is to be located in a 
compact build-up area. However, this presumption cannot be substantiated by a statistically significant result.

\subsection{Analysis, results}

In the initial stage, differences in the investigated factors between regenerated brownfields and deteriorating brownfields were examined and sorted by their previous uses. Looking at Table 2, which shows the correlation of individual dimension development with the decay or the regeneration of a certain site sorted by previous use, it is apparent that in some cases there really exists a demonstrable link. From the results, it is clear that statistically significant results can be observed only in the case of the site significance dimension of agricultural brownfields, while the same can be said for the economic profile dimension and the remains of touristic and recreational objects.

Table 2. The correlation of the state of brownfields according to previous use in dimensions (because of the absence of examples of regeneration the remains of mining and military activities were not included in the analysis).

\begin{tabular}{|l|r|r|r|r|r|r|}
\hline \multirow{2}{*}{$\begin{array}{l}\text { Independent } \\
\text { variables } \\
\text { (extracted } \\
\text { dimensions) }\end{array}$} & Regeneration & Agriculture & Amenities & Housing & Industry & Recreation \\
\cline { 2 - 8 } & -.006 & -.046 & -.032 & -.073 & .044 & -.299 \\
\hline $\begin{array}{l}\text { Socio- } \\
\text { economic } \\
\text { structure }\end{array}$ & .051 & -.154 & .081 & .071 & .137 & .249 \\
\hline $\begin{array}{l}\text { Peripheral } \\
\text { nature of } \\
\text { area }\end{array}$ & -.052 & .050 & -.129 & -.109 & -.004 & $-.882^{*}$ \\
\hline $\begin{array}{l}\text { Economic } \\
\text { profile }\end{array}$ & -.026 & $.260 *$ & -.028 & -.113 & -.095 & $.385^{*}$ \\
\hline $\begin{array}{l}\text { Significance } \\
\text { of area }\end{array}$ & -.071 & -.123 & -.062 & .061 & -.077 & .341 \\
\hline $\begin{array}{l}\text { Regional } \\
\text { devastation }\end{array}$ & & & & & & \\
\hline
\end{tabular}

Note: *. Correlation is significant at the 0.05 level (2-tailed).

Source: National strategy for the regeneration of brownfields, the Czech Statistical Office, own calculations.

Most of the brownfields that are now being used for agricultural purposes also had this usage in the past. Finding new uses for agricultural brownfields are usually made more difficult by the potential occurrence of extensive environmental contamination (as opposed to industrial brownfields, where risks can be localized fairly accurately based on the previous functions of a site) and difficult calculations of investment costs resulting from the often non-existent technical documentation, in addition to their generally unattractive position. Other common obstacles include complex property rights structure of the territory, as these were built on agricultural land that was, in many cases, parceled and returned to the descendants of the original farmers after the year 1990. The identified trend in the site significance dimension is then fully in line with the risks. It can be interpreted as the less regionally significant sites being regenerated because of the very low risk of the aforementioned obstacles. The analysis provided a statistically significant result for the 
development of the economic profile dimension in the case of recreational brownfields as well. This fact, however, can only be interpreted in a general way with great difficulty, as there were only five remains of tourist infrastructure identified in the examined region, with only one currently in use.

As was mentioned in the introduction, in addition to macro-economic causes of brownfield formation, factors influencing development in a particular scope of activity originally enabled by the brownfield also play a significant role. Original use of the property also played a major role in the choice of the location itself, with regards to other urban, socio-economic, and traffic infrastructure elements in the landscape. It can be assumed that the analysis of the data file sorted by previous site use has a greater predictive value. To validate this presumption, the existence of different values of the individual dimensions among the groups of regenerated brownfields sorted by previous use was investigated within the research. Table 3 captures the results of the variance analysis, which shows that statistically significant values appear only in the case of the second dimension.

Table 3. Variance analysis of the individual dimensions for regenerated brownfields according to previous use.

\begin{tabular}{|c|c|c|c|c|c|c|}
\hline \multicolumn{7}{|c|}{ ANOVA } \\
\hline & & $\begin{array}{l}\text { Sum of } \\
\text { Squares }\end{array}$ & df & $\begin{array}{l}\text { Mean } \\
\text { Square }\end{array}$ & $\mathrm{F}$ & Sig. \\
\hline \multirow{3}{*}{$\begin{array}{l}\text { Socio- } \\
\text { economic } \\
\text { structure }\end{array}$} & Between Groups & .000 & 5 & .000 & .723 & .607 \\
\hline & Within Groups & .000 & 370 & .000 & & \\
\hline & Total & .000 & 375 & & & \\
\hline \multirow{3}{*}{$\begin{array}{l}\text { Peripheral } \\
\text { nature of area }\end{array}$} & Between Groups & 3.454 & 5 & .691 & 2.893 & .014 \\
\hline & Within Groups & 88.372 & 370 & .239 & & \\
\hline & Total & 91.827 & 375 & & & \\
\hline \multirow{3}{*}{$\begin{array}{l}\text { Economic } \\
\text { profile }\end{array}$} & Between Groups & .582 & 5 & .116 & .725 & .605 \\
\hline & Within Groups & 59.431 & 370 & .161 & & \\
\hline & Total & 60.013 & 375 & & & \\
\hline \multirow{3}{*}{$\begin{array}{l}\text { Significance of } \\
\text { area }\end{array}$} & Between Groups & .800 & 5 & .160 & 1.124 & .347 \\
\hline & Within Groups & 52.693 & 370 & .142 & & \\
\hline & Total & 53.493 & 375 & & & \\
\hline \multirow{3}{*}{$\begin{array}{l}\text { Regional } \\
\text { devastation }\end{array}$} & Between Groups & .083 & 5 & .017 & .974 & .434 \\
\hline & Within Groups & 6.311 & 370 & .017 & & \\
\hline & Total & 6.394 & 375 & & & \\
\hline
\end{tabular}

Note: Statistically significant correlations are highlighted.

Source: The Czech Statistical Office, CzechInvest, own calculations (The CzechInvest Agency, 2008).

A more detailed testing uncovered that only the difference between former industrial areas and objects of civic amenities can be considered statistically significant on the basis of previous use, and only in the factors grouped in the second dimension (see Table 4). The results indicate that the regenerated brownfields which were used for the needs of the population in the past, most often as schools or service centers, are situated in municipalities where there are more devastated areas compared to the area of the village. In contrast, regenerated brownfields that were used for industrial purposes in the past, are most commonly located in the municipalities with a relatively small proportion of the devastated sites in the area. This finding may also be due to the fact that larger sites are 
usually required for industrial production than for amenities. However, this result can also be interpreted to imply that local authorities see a large number of brownfields as a risk factor and try to actively deal with the problem, which often results in objects which were in disrepair being restored in order to improve civic amenities. Usually, these changes were implemented by local politicians since municipalities could draw on a number of subsidies from public funds to construct objects of civic amenities in the reference period. The discovery that industrial remains are regenerated in more easily available areas than service objects is also related to this assumption. In the context of the examined region, the results of the analysis can be interpreted as the authorities of more remote municipalities with more brownfields apparently trying to make life more attractive. Regeneration occurs more often with objects of civic amenities, which in many cases, with the supports of grants from public sources, are meant to encourage social life because of their central position.

Table 4. Games-Howell test for newly used BF in the peripheral nature dimension according to the previous use of the site (because of the lack of relevant data the remains of recreational objects were discarded, as well as military brownfields because of the absence of a regenerated example.)

\begin{tabular}{|c|c|c|c|c|c|}
\hline \multirow[b]{2}{*}{$\mathrm{df}$} & \multicolumn{2}{|c|}{ Dependent Variable } & \multicolumn{3}{|c|}{ Multiple Comparisons } \\
\hline & $\mathrm{I}$ & $\mathrm{J}$ & $\begin{array}{c}\text { Mean } \\
\text { Difference } \\
(\mathrm{I}-\mathrm{J})\end{array}$ & $\begin{array}{l}\text { Std. } \\
\text { Error }\end{array}$ & Sig. \\
\hline \multirow[t]{4}{*}{12} & \multirow[t]{4}{*}{ Agriculture } & Amenities & -.068 & .061 & .871 \\
\hline & & Housing & -.047 & .091 & .995 \\
\hline & & Industry & .154 & .068 & .217 \\
\hline & & Tourism & .003 & .287 & 1.000 \\
\hline \multirow[t]{4}{*}{11} & \multirow[t]{4}{*}{ Amenities } & Agriculture & .068 & .061 & .871 \\
\hline & & Housing & .021 & .086 & 1.000 \\
\hline & & industry & .222 & .062 & .006 \\
\hline & & Tourism & .071 & .286 & 1.000 \\
\hline \multirow[t]{4}{*}{2} & \multirow{4}{*}{ Housing } & Agriculture & .047 & .091 & .995 \\
\hline & & Amenities & -.021 & .086 & 1.000 \\
\hline & & Industry & .202 & .092 & .254 \\
\hline & & Tourism & .050 & .294 & 1.000 \\
\hline \multirow[t]{4}{*}{17} & \multirow[t]{4}{*}{ Industry } & Agriculture & -.154 & .068 & .217 \\
\hline & & Amenities & -.222 & .062 & .006 \\
\hline & & Housing & -.202 & .092 & .254 \\
\hline & & Tourism & -.151 & .288 & .992 \\
\hline \multirow[t]{4}{*}{1} & \multirow{4}{*}{ Tourism } & Agriculture & -.003 & .287 & 1.000 \\
\hline & & Amenities & -.071 & .286 & 1.000 \\
\hline & & Housing & -.050 & .294 & 1.000 \\
\hline & & Industry & .151 & .288 & .992 \\
\hline
\end{tabular}

Source: The Czech Statistical Office, CzechInvest, own calculations (The CzechInvest Agency, 2008).

Finally, the statistical significance of the differences between the group of regenerated brownfields according to their new use in the individual dimensions was studied. The need for examining this variable is based on the assumption that spatial localization of activities carried out on the regenerated brownfields is determined by the requirements of the current company. The results of the verification of this phenomenon may therefore facilitate future treatment of the sites and enrich them with the recommended future use, supported by 
evidence. Based on the variance analysis statistically significant differences were identified, again in the peripheral nature dimension (see Table 5). The results of the Games-Howell test show that in this dimension there is a statistically significant difference between regenerated sites which have found new uses in agriculture, and objects used for production or amenities (see Table 6).

Table 5. Variance analysis of regenerated brownfields in dimensions.

\begin{tabular}{|c|c|c|c|c|c|c|}
\hline \multicolumn{7}{|c|}{ ANOVA } \\
\hline & & $\begin{array}{l}\text { Sum of } \\
\text { Squares }\end{array}$ & df & Mean Square & F & Sig. \\
\hline \multirow[t]{3}{*}{$\begin{array}{l}\text { Socio-economic } \\
\text { structure }\end{array}$} & $\begin{array}{l}\text { Between } \\
\text { Groups }\end{array}$ & .000 & 3 & .000 & .453 & .716 \\
\hline & $\begin{array}{l}\text { Within } \\
\text { Groups }\end{array}$ & .000 & 43 & .000 & & \\
\hline & Total & .000 & 46 & & & \\
\hline \multirow[t]{3}{*}{$\begin{array}{l}\text { Peripheral nature } \\
\text { of area }\end{array}$} & $\begin{array}{l}\text { Between } \\
\text { Groups }\end{array}$ & 2.110 & 3 & .703 & 3.844 & .016 \\
\hline & $\begin{array}{l}\text { Within } \\
\text { Groups }\end{array}$ & 7.867 & 43 & .183 & & \\
\hline & Total & 9.977 & 46 & & & \\
\hline \multirow[t]{3}{*}{ Economic profile } & $\begin{array}{l}\text { Between } \\
\text { Groups }\end{array}$ & .131 & 3 & .044 & .181 & .909 \\
\hline & $\begin{array}{l}\text { Within } \\
\text { Groups }\end{array}$ & 10.359 & 43 & .241 & & \\
\hline & Total & 10.489 & 46 & & & \\
\hline \multirow[t]{3}{*}{$\begin{array}{l}\text { Significance of } \\
\text { area }\end{array}$} & $\begin{array}{l}\text { Between } \\
\text { Groups }\end{array}$ & .369 & 3 & .123 & 1.193 & .324 \\
\hline & $\begin{array}{l}\text { Within } \\
\text { Groups }\end{array}$ & 4.437 & 43 & .103 & & \\
\hline & Total & 4.806 & 46 & & & \\
\hline \multirow[t]{3}{*}{$\begin{array}{l}\text { Regional } \\
\text { devastation }\end{array}$} & $\begin{array}{l}\text { Between } \\
\text { Groups }\end{array}$ & .099 & 3 & .033 & 2.037 & .123 \\
\hline & $\begin{array}{l}\text { Within } \\
\text { Groups }\end{array}$ & .694 & 43 & .016 & & \\
\hline & Total & .792 & 46 & & & \\
\hline
\end{tabular}

Source: The Czech Statistical Office, CzechInvest, own calculations (The CzechInvest Agency, 2008).

The results of the Games-Howell test show that brownfields newly used for agricultural activity display significantly lower values in the peripheral nature dimension than objects newly used for industrial production or for civic amenities (see Table 6). Brownfields reclaimed for agricultural purposes are therefore located in municipalities with a relatively less significant proportion of devastated area than sites used for industry and services. Almost three quarters $(73 \%)$ of the current objects of civic amenities also served this purpose in the past, the explanation of this fact can be found in the attempts of local authorities to actively deal with brownfields, improve the civic amenities, and make a municipality distant from the region administrative center more attractive. 
Table 6. Games-Howell test for BF in the peripheral nature dimension according to the current use of the site (Because of the lack of relevant data one case of a new apartment building was discarded).

\begin{tabular}{|c|c|c|c|c|c|}
\hline & \multicolumn{5}{|c|}{ Multiple Comparisons } \\
\hline & \multicolumn{2}{|c|}{ Dependent Variable } & \multirow{2}{*}{$\begin{array}{c}\text { Mean } \\
\text { Difference } \\
(\mathrm{I}-\mathrm{J})\end{array}$} & \multirow[t]{2}{*}{ Std. Error } & \multirow[t]{2}{*}{ Sig. } \\
\hline df & I & $\mathrm{J}$ & & & \\
\hline \multirow[t]{3}{*}{5} & \multirow[t]{3}{*}{ Agriculture } & Amenities & -.764 & .228 & .009 \\
\hline & & Greenfield & -.568 & .287 & .212 \\
\hline & & Industry & -.609 & .209 & .028 \\
\hline \multirow[t]{3}{*}{12} & \multirow[t]{3}{*}{ Amenities } & Agriculture & .764 & .228 & .009 \\
\hline & & Greenfield & .196 & .247 & .856 \\
\hline & & Industry & .155 & .149 & .726 \\
\hline \multirow[t]{3}{*}{4} & \multirow[t]{3}{*}{ Greenfield } & Agriculture & .568 & .287 & .212 \\
\hline & & Amenities & -.196 & .247 & .856 \\
\hline & & Industry & -.041 & .230 & .998 \\
\hline \multirow[t]{3}{*}{26} & \multirow[t]{3}{*}{ Industry } & Agriculture & .609 & .209 & .028 \\
\hline & & Amenities & -.155 & .149 & .726 \\
\hline & & Greenfield & .041 & .230 & .998 \\
\hline
\end{tabular}

Source: The Czech Statistical Office, CzechInvest, own calculation (The CzechInvest Agency, 2008).

When interpreting the difference in values of industrial and agricultural sites, it is necessary to take into account the average size of regenerated sites, since the new brownfields newly used for agriculture have an average area of 3 ha, while the new industrial areas have an average of 10 ha, which can be one of the causes of the observed outcome, especially in cases where there is only one newly used brownfield in the municipality. Relatively high values of industrial brownfields in the second dimension correspond to the fact that objects whose dispositions and structure are suitable for production purposes regeneration are often located in traditional industrial areas (Kolejka, Klimánek \& Fragner, 2011) of the region, where a higher occurrence of devastated objects can generally be expected, be it remains industrial, residential or civic amenities objects.

Most frequently, brownfields which also served this purpose in the past, are regenerated for industrial utilization. When searching for the causes of the results obtained, the physical-geographical breakdown of the region and its economic past must therefore be taken into account. The location of the remains of the industrial past often corresponds to the specific needs of the sector at a time when the region was dominated by the textile industry. The industry was allocated in less accessible areas, which, however, had the necessary energy sources - primarily water and wood. For this reason, the industrial operations were often built in the inhospitable mountainous areas, while traditional administrative centers were created in the fertile lowlands. These specific late 19th century requirements of textile production are then necessarily reflected in the high values of the regenerated industrial sites in the second dimension, and in the relatively low values of the brownfields used for agriculture.

As mentioned above, the regenerated objects as the remains of services and trade are mostly located in more remote parts of the examined territory, as representatives of the local authorities see the increase in civil amenities as a way to attract new residents and retain existing ones. This seems like one of the causes of the higher values that brownfields 
regenerated for civic amenities have in the second dimension, compared to the sites regenerated for the purposes of agriculture.

\section{DISCUSSION AND CONCLUSION}

The aim of the research was investigation of the links of devastated sites to the environment of their occurrence. On the basis of the results, the following conclusions can be deduced:

- The investment risk is one of the main reasons why investors tend to prefer building on greenfields, as opposed to realizing their intentions on brownfields. Because of this, relatively small brownfields are usually regenerated with regard to the urbanized area, where there are charted risks related to the works. This claim is clearly demonstrable in the examined region, especially in the case of remains of agricultural activity (the second largest group of brownfields).

- Compared to the largest group - industrial brownfields - both deteriorating and regenerated agricultural areas are less distinctive in the urban structure, which is understandable in view of the greater expanse of industrial areas.

- The examined region is specific for its residential and economic structure, which is characterized by its rural, yet significantly industrialized character (Kolejka, Klimánek \& Fragner, 2011). A phenomenon which can be generalized for the entirety of the Czech Republic is more apparent thanks to this specific distribution of human activity - both regenerated brownfields and brownfields in disrepair which used to be objects of civic amenities are located in relatively remote and structurally dejected areas. The cause of their origin can be found in the unnatural spatial allocation of services and trade in a rural area in the period before 1989, which became unsustainable after the reorientation of the economy, de-industrialization and depopulation activity in the countryside.

- The cause of the regeneration of trade objects remains can be found in activities by local authorities, which try to build a high-quality environment for residents and a more attractive municipality by regenerating public spaces (including civic amenities). This is one of the possible forms of "defense" against the depopulation of peripheral areas in a time of continuing migration of inhabitants into larger cities.

- On the other side, the renewed industrial brownfields are located in larger municipalities, where economic life is naturally more dynamic than in smaller settlements. At the same time industrial brownfields are more frequently finding new uses in centers of industrial regions, which may benefit from their industrial tradition in spite of structural changes. The tradition is also reflected in the structure of technical education in the region (middle and higher education tied to technical subjects as well as specific industrial enterprises).

Previous research, dealing with the identification of the factors critical to the development potential of brownfields, have identified a link between local entrepreneurial activity (Frantál et al, 2013) and the prosperity of the region, to the potential of a devastated site to find new use (Longo \& Campbell, 2016). Among the other factors playing a role in the regeneration of brownfields are position in relation to the municipality center, or public transportation (Lange \& McNeil, 2004 ). In the examined region, most of the remains of the previous industrial production is situated outside of the administrative center, and the 
region itself shows a more rural type of settlement. Osman et al (2015) identified an asymmetry in the investments into brownfields in rural areas and in cities in favor of larger settlements. These findings correspond partially to the results presented here, which, however, can only be applied to regenerated brownfields that have found a new use in agriculture.

Since brownfields were regarded as development areas in terms of their location and functional dispositions, factors often mentioned as key were downplayed when assessing regeneration potential. At the same time, the physical-geographical division of the terrain and urban structure of the examined region was reflected in the data file, imposing increased demands on the exact formulation of the findings. The occurrence of environmental contamination has not been taken into account in the work, as its existence lacks importance in connection to environment attractiveness (Frantál et al, 2013). The used data file also disregards the ownership structure and the potential uses with regard to the valid territorial planning documentation, since the aim of the research was to determine mostly the territorial-technical, geographical, economic and socio-demographic links in the territory where existing and regenerated brownfields occur, within the intentions of regional significance of the site and devastation of the region. In the assessment of brownfield regeneration, however, the involvement of local citizens, business owners, political authorities and other stakeholders is often pivotal (De Sousa, 2000). Their proactive attitude is often a fundamental condition for successful brownfield regeneration.

A number of works, which constructed tools for attractive brownfield identification on the basis of geomorphological indicators worked with a more compact area, more specifically towns (e.g. Chrysochoou et al, 2012, Frantál et al, 2015). This way the prospective land use in the vicinity of the examined site could be used efficiently as a factor in determining the future use of the brownfield itself. This aspect, however, does not seem to be suitable for analyzing data files, which also contain rural brownfields, since those may not be located within the municipality, the function of which would create pressure on compact urbanistic solutions of the area. An excessive amount of consistency when applying the methodology of previous research was revealed over the course of the research. Considering the construction of factor analysis methodology which is being applied in brownfield analysis, it is recommended that in the future during initial construction of the file of evaluated factors the characteristics of the area are considered more thoroughly. This is true especially for the already known or presumed characteristics of both the urban relief and the neglected areas. In this respect, the presumption about the significance of territorial relations ensuing from the ratio of variously utilized areas, including brownfields, was not proven.

Excessively literal over-taking of methodology caused several issues during analysis, which could have caused results to be difficult to interpret. Historically, the examined region was strongly economically focused on the textile industry. In order to generalize the results, for example to the level of Central and Eastern European countries, it would be advisable to perform similar analyses in other traditionally industrial regions, where similar results can be expected. The most significant obstacle in this endeavor can be the virtual (non)existence of relevant data and their subjective interpretation.

As a recommendation for future research work with a similar direction, it is appropriate to ensure a greater compactness of data, whether from the territorial point of view or from the character of the collected information. Acquisition of stronger results can then be expected. In practice, these results may have a major impact on decision-making processes during prioritizing and scaling brownfields in the area. The evaluation of territorial context 
in functional terms should be the contribution of future works. Land utilization in the immediate surroundings of brownfields or distance from a specific type of area may in fact fundamentally predict and identify the pressure that is created on a particular site in terms of its future use.

\section{ACKNOWLEDGEMENT}

This contribution was supported by the internal project of Faculty of Economics and Administration, Masaryk University (MUNI/A/0896/2015) and by the project Brownfields in urban and rural space: geographic, economic, historical, legal contexts and their importance for regional development (BURAN) (SGS/21/2016) and by the project New methods for the more effective regeneration of brownfields to enable optimizing of the decision making processes (TD020259, Technology Agency of the Czech Republic).

\section{R E F E R E N C E S}

Adair, A., Berry, J., McGreal, S., Deddis, B. \& Hirst, S. (2000) The Financing of Urban Regeneration. Land Use Policy, 17 (2), 147-156.

Adair, A., Berry, J., McGreal, S. \& Quinn, A. (2002) Factors Affecting the Level and Form of Privat Investment in Regeneration. Newtonsabbey: Centre for Research on Property and Planning.

The CzechInvest Agency (2008) Základní statistické výsledky Vyhledávací studie brownfieldů. Ministerstvo průmyslu a obchodu. [Online]. Available at: http:www.czechinvest.org/data/files/nsb-595.pdf. [Accessed 23rd October 2015].

Agostini, P. \& Vega, A. (2007) Decision Support Systems (DSSs) for Contaminated Land Management - Gaps and Challenges. In Marcomini, A., Suter. G. W., Critto, A. (Eds) Decision Support Systems for Risk-Based Management of Contaminated Sites. Heidelberg: Springer, 275280.

Anand, S. \& Amatya, K. S. (1994) Human Development Index: Methodology and Measurement. New York: Human Development Report Office Occasional, Paper 12.

Ascough, J. C., Maier, H. R., Ravalico, J. K. \& Strudley, M. W. (2008) Future Research Challenges for Incorporation of Unvertainity in Environmental and Ecologcal Decision-making. Ecological Modelling, 219, 383-399.

Bardos, P. R., Nathanail, C. P. \& Weenk, A. (2000) Assessing the Wider Value of Remediating Land Contamination: A Review. R\&D Report P238. Bristol: UK Environmental Agency.

Bayer, P., Finkel, M. \& Teutsch, G. (2005) Cost-optional Contaminant Plume Management with a Combination of Pump-and-treat and Physical Barrier Systems. Groundwater Monitoring \& Remediation, 25, (2), 96-106.

Bernard, J. (2011) Endogenní rozvojové potenciály malých venkovských obcí - obtížné hledání a měření jejich vlivu. Sociologický časopis, 47 (4), 745-775.

Carlon, C., Critto, A., Ramieri, E. \& Marcomini, A. (2007) DESYRE: Decision Support System for the Rehabilitation of Contaminated Megasites. Integrated Environmental Assessment \& Management, 3 (2), 211-222.

De Sousa, C. A. (2000) Brownfield Redevelopment Versus Greenfield Redevelopment: A Private Sector Perspective on the Cost and Risks Associated with Brownfield Redevelopment in the Greater Toronto Area. Journal of Environmental Planing \& Management, 43 (6), 831-853.

Doetsch, P. \& RÜPKE, A. (1998) Revitalisierung von Altstandorten versus Onanspruchnahme von Naturflächen. Berlin: Umweltbundesamt.

Duinker, P. N. \& Greig, L. N. (2007) Scenario Analysis in Environmental Impact Assessment: Improving Explorations of the Future. Environmental Impact Assessment Review. 27, 206-219.

Ferber, U., Jackson, J. B. \& Starzewski-Sikorska, A. (2011) Circular Flow Land Use Management. Proceedings Real Corp., 201118-20 May 2011, Essen, Germany. 
Filip, S. \& Cocean, P. (2012) Urban Industrial Brownfields: Constraints and Opportunities in Romania. Carpathian Journal of Earth and Environmental Sciences, 7 (4), 155-164.

Frantál, B., Kunc, J., Nováková, E., Klusáček, P., Martinát, S. \& Osman, R. (2013) Location Matters! Exploring Brownfields Regeneration in a Spatial Context (A Case Study of the Southern Moravian Region, Czech Republic). Moravian Geographical Reports, 21 (2), 5-19.

Frantál, B., Greer-Wootten, B., Klusáček, P., Krejčí, T., Kunc, J. \& Martinát, S. (2015) Exploring Spatial Patterns of Urban Brownfields Regeneration: The Case of Brno, Czech Republic. Cities, 44, 9-18.

Gregory, R. \& Slovic, P. (1997) A ConstructiveApproach to Environmental Valuation. Ecological Economics, 21 (3), 175-181.

Hayek, M., Novak, M., Arku, G. \& Gilliland, J. (2010) Mapping Industrial Legacies: Building a Comprehensive Brownfields Database in Geographic Information System. Planning Practice \& Research, 25, (4), 461-475.

Chrysochoou, M., Brown, K., Dahal, G., Granda-Carvajal, C., Segerson, K., Garrick, N. \& Bagtzoglou, A. (2012) A GIS and Indexing Scheme to Green Brownfields for Area-Wide Redevelopment Planning. Landscape and Urban Planning, 105,187-198.

Jakeman, A. J., Chen, S. H., Rizzoli, A. E. \& Voinov, A. A. (2008) Modelling and Software as Instruments for Advancing Sustainabillity. In Jakeman, A.J., Chen, S.H., Rizzoli, A.E., Voinov, A.A. (Eds) Environmental Modeling, software and Decision Support 3, Elsevier Science, 1-13.

Klusáček, P., Krejčí, T., Kunc, J., Martinát, S. \& Nováková, E. (2011) The Post-Industrial Landscape in Relation to Local Self-Government in the Czech Republic. Moravian Geographical Reports, $19,(4), 18-28$.

Kolejka, J., Klimánek, M. \& Fragner, B. (2011) Post-Industrial Landscape: The Case of the Liberec Region, Czech Republic. Moravian Geographical Reports, 19, (4), 3-17.

Kreinin, A., Merkoulovitch, L., Rosen, D. \& Zerbs, M. (1998) Measuring Portfolio Risk Using Quasi Monte Carlo Methods. Algo Research Quarterly, 1, (1), 17-26.

Kunc, J., Navrátil, J., Tonev, P., Frantál, B., Klusáček, P., Martinát, S., Havlíček, M. \& Černík, J. (2014) Perception of Urban Renewal: Reflexions and Coherences of Socio-Spatial Patterns (Brno, Czech Republic). Geographia Technica, 9, (1), 66-77.

Lange, D. \& McNeil, S. (2004) Clean it and They Will Come? Defining Successful Brownfield Development. Journal of Urban Planning and Development, 130, (2), 101-108.

Longo, A. \& Campbell, D. (2016) The Determinants of Brownfields Redevelopment in England. Environmental and Resources Economics (in press).

Malczewski, J. (2006) GIS-Based Multicriteria Decision Analysis: A Survey of the Literature. International Journal of Geographical Information Science, 20, (7), 703-726.

McKnight, U. S., Funder, S. G., Rasmussen, J. J., Finkel, M., Binning, P. J. \& Bjerg, P. L. (2010) An Integrated Model for Assessing the Risk of TCE Groundwater Contamination to Human Receptors and Surface Water Ecosystems. Ecological Engineering, 36, (9), 1126-1137.

Nijkamp, P., Rodenburg, C. A. \& Wagtendonk, A. J. (2002) Success Factors for Sustainable Urban Brownfield Development: A Comparative Case Study Approach to Polluted Sites. Ecological Economics, 40, (2), 235-252.

Oliver, L., Ferber, U., Grimski, D., Milliar, K. \& Nathanail, P. (2005) The scale and nature of European brownfield. [Online]. Available at: http:// https://www.researchgate.net/profile/Uwe_Ferber/publication/228789048_The_Scale_and_Natur e_of_European_Brownfield/links/5469e8300cf20dedafd20077.pdf?origin=publication_detail. [Accessed 25th May 2016].

Osman, R., Frantál, B., Klusáček, P., Kunc, J. \& Martinát, S. (2015) Factors Affecting Brownfield Regeneration in Postsocialist Space: The Case of the Czech Republic. Land Use Policy, 48, 309316. 
Popescu, G. \& Pătrăşcoiu, R. (2012) Brownfield Sites - Between Abandonment and Redevelopment. Case Study: Craiova City. Human Geographies - Journal of Studies and Research in Human Geography, 6 (1), 91-97.

Prato, T. (2007) Evaluating Land Use Plans Under Uncertainty. Land Use Policy, 24, 165-174.

Rydvalová, P. (2006) Možnosti regenerace vybrané hospodářské oblasti. E+M Ekonomika a Management, 9, (2), 49-57.

Schädler, S., Morio, M., Bartke, S., Rohr-Zänker, R. \& Finkel, M. (2011) Designing Sustainable and Economically Attractive Brownfields Revitalization Options Using an Integrated Assessment Model. Journal of Environmental Management, 92, (3), 827-837.

Stezar, I. C., Pizzol, L., Critto, A., Ozunu, A. \& Marcomini, A. (2013) Comparison of Risk-Based Decision-Support Systems for Brownfield Site Rehabilitation: DESYRE and SADA Applied to a Romanian Case Study. Journal of Environmental Management. 131, 383-393.

Tam, E. K. L. \& Byer, P. H. (2002) Remediation of Contaminated Lands: A Decision Methodology for Sites Owners. Journal of Environmental Management, 64, 387-400.

Tabachnik, B. G. \& Fidell, L. S. (2001) Principal Components and Factor Analysis. In Using Multivariate Statistics (4th ed.). Needham Heights, MA: Allyn \& Bacon, 582-633.

Viturka, M., Halámek, P., Klímová, V., Tonev, P. \& Žítek, V. (2010) Kvalita podnikatelského prostředí, regionálni konkurenceschopnost a strategie regionálního rozvoje České republiky. Praha: Grada Publishing.

Wedding, G. C. \& Crawford-Brown, D. (2007) Measuring Site-Level Success in Brownfield Redevelopments: A Focus on Sustainability and Green Building. Journal of Environmental Management, 85, 483-495. 